\title{
Growth characteristics and phenylalanine ammonia-lyase activity in peach grafted on different Prunus spp.
}

\author{
I. DOS SANTOS PEREIRA ${ }^{1}$, R. DA SILVA MESSIAS ${ }^{2}, \hat{A}$. DINIZ CAMPOS $^{3}$, P. ERREA $^{4}$, \\ L.E. CORRÊA ANTUNES ${ }^{1}$, J.C. FACHINELLO ${ }^{5}$, and A. PINA ${ }^{4 *}$
}

Departamento de Fruticultura ${ }^{1}$, Departamento de Biologia Molecular ${ }^{2}$, and Departamento de Fisiologia Vegetal ${ }^{3}$, Embrapa Clima Temperado, Pelotas, 96010-971, Brazil

Unidad de Fruticultura, Centro de Investigación y Tecnología Agroalimentaria de Aragón,

Zaragoza, E- 50059, Spain ${ }^{4}$

Departamento de Fitotecnia, Universidade Federal de Pelotas, Pelotas, 96001-970, Brazil ${ }^{5}$

\begin{abstract}
Phenylalanine ammonia lyase (PAL) is a key enzyme in the phenylpropanoid pathway responsible for biosynthesis of many secondary metabolites, such as anthocyanins, flavanols, and lignins. The objective of this work was to determine the effect of different rootstock/scion combinations on Prunus tree growth, $P A L$ gene expression, and PAL activity in order to identify compatibility of different graft combinations. The study was performed with peach $(P$. persica cv. Chimarrita) grafted on two peach rootstocks (Capdeboscq and Tsukuba1) and one Japanese apricot (P. mume $\mathrm{cv}$. Umezeiro). Two or three years after grafting, the growth of peach scion on Umezeiro was weak and finally the death of some trees occurred. The peach rootstocks induced vigorous growth without any tree loss through the three years of evaluation. However, PAL activity and expression of PAL encoding genes were higher in Umezeiro as compared to the other rootstocks. These results show that the differential gene expression together with the PAL activity is a promising strategy to predict graft incompatibility.
\end{abstract}

Additional key words: phenylpropanoid pathway, Prunus mume, Prunus persica, rootstock-scion compatibility, secondary metabolism.

\section{Introduction}

Grafting is a technique widely used in horticulture, whereby a scion and a rootstock, generally belonging to the same botanical species or to species of the same genus, are joined together. However, when grafting involves two different species or genera, a lack of affinity known as graft incompatibility may occur (Hartmann et al. 2002). Graft incompatibility is a relevant problem for development of new rootstocks, especially in fruit species, where the external symptoms of incompatibility may appear several years after grafting (Errea and Felipe 1993, Hartmann et al. 2002). Nowadays, new Japanese apricots as rootstocks for peaches are being introduced into São Paulo State, Brazil, mainly due to their promising characteristics, such as the induction of a

reduced vigour and of good fruit quality, as well as their possible resistance to root-knot nematodes (Comioto et al. 2012). However, their compatibility with Brasilian peach cultivars has not been tested.

The sequence of structural events during graft development in plants has been widely described (Errea et al. 1994, Ermel et al. 1997, Hartmmann et al. 2002, Pina and Errea 2005). The formation of the graft union can be considered as the result of the following steps: 1) establishment of an intimate contact between the cambial regions of rootstock and scion, and formation of the callus tissue that soon intermingles and interlocks, filling up the spaces between scion and rootstock; 2) differentiation of vascular cambium across the callus

Submitted 21 December 2012, last revision 20 May 2013, accepted 19 June 2013.

Abbreviations: CTAB - cetyltrimethylammonium bromide; PAL - phenylalanine ammonia lyase; RP II - RNA polymerase II; t-CA - trans-cinnamic acid; TEF2 - translation elongation factor 2.

Acknowledgements: The authors highly appreciate the comments and suggestions of Dr. Rafael Socias. This research was supported by Coordenação de Aperfeiçoamento de Pessoal de Nível Superior (CAPES), Conselho Nacional de Desenvolvimento Científico e Tecnológico (CNPq), Brazilian agencies from Ministério da Ciência e Tecnologia (MCT), and the Spanish grant RTA2009-00128 from the Instituto Nacional de Investigación y Tecnología Agraria y Alimentaria (INIA).

* Corresponding author; fax: (+34) 976716335, e-mail: apina@aragon.es 
bridge, and 3) production of new xylem and phloem from the new vascular cambium in the callus bridge, forming the vascular connections necessary for a successful graft union. Although the latest step is considered as the basic requirement for a successful graft in herbaceous plants (Moore and Walker 1981, Aloni et al. 2010), in fruit trees, different cell behaviour takes place in early graft development (Errea et al. 1994, 2001) and vascular connections are established even in incom-patible unions (Ermel et al. 1997, Espen et al. 2005).

Several lines of recent research link the graft incompatibility with differences in accumulation of phenolic compounds (Errea 1998, Usenik et al. 2006, Mng'omba et al. 2008) synthetized by the phenylpropanoid pathway. These compounds are often induced under biotic or abiotic stresses and are involved in several metabolic processes (Anterola and Lewis 2002, Jin et al. 2012). Otherwise, high content of phenolic compounds is associated with damages during graft formation, limiting the proliferation and differentiation of callus, as well as the formation of the new vascular tissues in incompatible grafts (Feucht et al. 1988, Hartmann et al. 2002).

\section{Materials and methods}

Plants and experimental design: Peach [Prunus persica (L.) Batsch] cv. Chimarrita was grafted on two peach (cvs. Capdeboscq and Tsukuba1) and one Japanese apricot (Prunus mume Sieb. et Zucc. cv. Umezeiro) rootstocks. Grafts were made by chip budding and grafted plants were grown in the field at the Federal University of Pelotas, Brazil. Chimarrita/Umezeiro combination has been suggested to exhibit signs of graft incompatibility (Teles et al. 2009, Comioto et al. 2012), but no specific analysis of graft compatibility were carried out. Bark samples were collected two years after grafting $5 \mathrm{~cm}$ above and below the graft union for each grafted combination. All samples were immediately frozen in liquid nitrogen and stored at $-80{ }^{\circ} \mathrm{C}$ until analyses.

The following variables were measured: cumulative pruning fresh mass, leaf area, trunk diameter, index of survival, and chlorophyll content. The fresh mass of pruning material was taken at the first and second year after grafting. Leaf area was evaluated at the second year after grafting and the trunk diameter was measured throughout three years. Chlorophyll content was determined using a SPAD 502 (Minolta, Osaka, Japan) $150 \mathrm{~d}$ after full bloom two years after grafting. The internal evaluation of the different graft unions were done according to Herrero (1951).

Real time qRT-PCR expression analysis: Total RNA was isolated using the CTAB protocol adapted by Messias et al. (2010). Determination of quality and quantification of total RNA were performed by $1 \%(\mathrm{~m} / \mathrm{v})$ agarose gel electrophoresis and spectrophotometer analysis (Nanodrop 1000, Thermo Scientific, Wilmington, DE, USA). Total RNA (1 $\mu \mathrm{g})$ was reverse transcribed
Nevertheless, it is still not clear if induced phenolic accumulation is the cause or the consequence of the scion-rootstock incompatibility.

The first enzyme in the phenylpropanoid pathway is the phenylalanine ammonia lyase (PAL; EC 4.3.1.24), responsible for coordinating this pathway. PAL is regulated at the transcriptional level in response to different stresses, such as pathogenic attack, UV radiation, low supply of nitrogen, phosphate, or iron, as well as rootstock/scion interactions (Dixon and Paiva 1995, Kubota et al. 2001, Leng and Qui 2003, Olsen et al. 2008, Pina and Errea 2008, Sullivan et al. 2009). High PAL transcription was observed in incompatible combinations of apricot/plum resulting in a high accumulation of phenolic compounds (Pina and Errea 2008). Thus, the induction of PAL transcription can be related to the scion-rootstock compatibility.

In the present study, the effects of different rootstockscion interactions on several growth characteristics were correlated with gene expression and activity of PAL in order to examine their possible roles in graft incompatibility in some Prunus combinations.

using an oligo $(\mathrm{dT})_{20}$ and SuperScript $\mathbb{R}$ III first-strand synthesis kit according to the manufacturer's instructions (Invitrogen, Madrid, Spain). Specific primers for PAL1 (ppa002099m) and PAL2 (ppa002328m) were designed based on the nucleotide sequence of peach on GDR (genome database of Rosaceae - http://www. rosaceae.org). The reactions were performed on a 7500/7500 Fast equipment (Applied Biosystems, Carlsbad, CA, USA). The reactions comprised a total volume of $25 \mathrm{~mm}^{3}, 12.5 \mathrm{~mm}^{3}$ of the SYBR ${ }^{\circledR}$ Green PCR master mix (Applied Biosystems), $5 \mathrm{~mm}^{3}$ of cDNA, and $300 \mathrm{nM}$ primers. The protocol was identical for all primer sets: $95{ }^{\circ} \mathrm{C}$ for $10 \mathrm{~min}$, followed by 40 cycles at $95{ }^{\circ} \mathrm{C}$ for $30 \mathrm{~s}$; $60{ }^{\circ} \mathrm{C}$ for $1 \mathrm{~min}, 72{ }^{\circ} \mathrm{C}$ for $1 \mathrm{~min}$; and a final extension of $72{ }^{\circ} \mathrm{C}$ for $10 \mathrm{~min}$. Afterwards, the specificity of the amplification products was determined using a melting curve in all cases using the following melting curve program: $95^{\circ} \mathrm{C}$ for $15 \mathrm{~s}, 60^{\circ} \mathrm{C}$ for $15 \mathrm{~s}$, and $95{ }^{\circ} \mathrm{C}$ for $15 \mathrm{~s}$. Two technical replications for each of the 3 biological replicates were performed. The expression of target genes were normalized with reference genes using the comparative $\mathrm{Ct}$ method at constant fluorescence. The reference genes tested were actin $(A C T 11)$, translation elongation factor (TEF2), RNA polymerase II (RP II), and EST (GenBank accession No. DY652828). Specificity of amplicons was verified on a $2.5 \%(\mathrm{~m} / \mathrm{v})$ agarose gel with bromide staining. Primers sequences are shown in Table 1. Real-time PCR efficiency and correlation coefficients $\left(R^{2}\right)$ of the genes were determined by a $\operatorname{LinRegPCR}$ software (Ruijter et al. 2009). The stability analysis of the housekeeping genes was carried out by a NormFinder algorithm adapted for Microsoft Excel according to Andersen et al. (2004) and Tong et al. (2009). 
PAL activity: PAL activity was determined according to the method described by Campos et al. (2003). The activity was determined in crude bark extracts, obtained by grinding the bark with $4 \mathrm{~cm}^{3}$ of $0.5 \mathrm{M}$ borate buffer containing $0.05 \mathrm{~g}$ of polyvinylpyrrolidone (PVP) in a Polytron mixer at full speed and $4{ }^{\circ} \mathrm{C}$, after filtration (Whatman 1) and centrifugation (25000 g, $15 \mathrm{~min}$ ). The readings were taken at $290 \mathrm{~nm}$ in a PC Shimadzu (Kyoto, Japan) UV-1601 PC spectrophotometer. The enzyme activity was expressed in units that are defined as the amount of an enzyme that produces $1 \mathrm{mM}$ trans-cinnamic acid (t-CA) per min. Protein content was determined according to the method of Bradford (1976) with bovine serum album (BSA) as a standard.

Statistical analysis: Data were evaluated by analysis of variance with the statistical program SPSS v. 15.0 (SPSS, Chicago, USA). When the differences were statistically significant $(P<0.05)$, the Tukey's test was used for comparison of means.

Table 1. Primer sequences used for PAL1, PAL2, and reference genes (Actin, RPII, TEF2, and EST) expression analyses. Forward (F) or reverse $(\mathrm{R})$ orientation of each primer is indicated. Real Time qPCR efficiency and correlation coefficients $\left(R^{2}\right)$ were determined by the LinRegPCR software.

\begin{tabular}{|c|c|c|c|c|c|c|}
\hline Primer & & Primer sequences $\left(5^{\prime}-3^{\prime}\right)$ & $\operatorname{Tm}\left[{ }^{\circ} \mathrm{C}\right]$ & Amplicon size $[\mathrm{bp}]$ & Efficiency & $R^{2}$ \\
\hline \multirow[t]{2}{*}{ PAL1 } & $\mathrm{F}$ & ATGAGGTGAAGCGCATGGTG & 62 & \multirow[t]{2}{*}{85} & \multirow[t]{2}{*}{1.941} & \multirow[t]{2}{*}{0.9994} \\
\hline & $\mathrm{R}$ & CTATGGCAGCCACTTGGGAA & 62 & & & \\
\hline \multirow[t]{2}{*}{$P A L 2$} & $\mathrm{~F}$ & AGGTCAAACGGATGGTCAAC & 58 & \multirow[t]{2}{*}{85} & \multirow[t]{2}{*}{1.974} & \multirow[t]{2}{*}{0.9995} \\
\hline & $\mathrm{R}$ & ATTGCAGCCACCTGAGCTAT & 60 & & & \\
\hline \multirow[t]{2}{*}{ Actin } & $\mathrm{F}$ & TGAGGCTCCTCTCAACCCTA & 62 & \multirow[t]{2}{*}{82} & \multirow[t]{2}{*}{1.978} & \multirow[t]{2}{*}{0.9987} \\
\hline & $\mathrm{R}$ & ATACATGGCAGGCACATTGA & 58 & & & \\
\hline \multirow[t]{2}{*}{$R P I I$} & $\mathrm{~F}$ & TGAAGCATACACCTATGATGATGAAG & 60 & \multirow[t]{2}{*}{128} & \multirow[t]{2}{*}{1.945} & \multirow[t]{2}{*}{0.999} \\
\hline & $\mathrm{R}$ & CTTTGACAGCACCAGTAGATTCC & 60 & & & \\
\hline \multirow[t]{2}{*}{$T E F 2$} & $\mathrm{~F}$ & GGTGTGACGATGAAGAGTGA & 60 & \multirow[t]{2}{*}{129} & \multirow[t]{2}{*}{1.940} & \multirow[t]{2}{*}{0.9993} \\
\hline & $\mathrm{R}$ & AAGGAGAGGGAAGGTGAAAG & 60 & & & \\
\hline \multirow[t]{2}{*}{ EST } & $\mathrm{F}$ & AGTCAGCCCAGTACGAAGAGG & 60 & \multirow[t]{2}{*}{152} & \multirow[t]{2}{*}{1.910} & \multirow[t]{2}{*}{0.9999} \\
\hline & $\mathrm{R}$ & TGCTTCTGCTTCACCCACCT & 60 & & & \\
\hline
\end{tabular}

\section{Results and discussion}

Plant grafting is a widely used means of plant propagation, but its range of application is restricted by physiological, anatomical, and biochemical factors that produce incompatible grafts. It is widely known that productivity in peach orchards may be difficult to achieve without compatible grafting of scions and size controlling rootstocks (Reighard 2000). In this work, the effects of different rootstock-scion interactions in several vegetative growth characteristics as well as in PAL activity and gene expression were studied in different grafted Prunus species. Less cumulative fresh mass of pruning material, leaf area, and index of survival during the second and third year after grafting were found in Chimarrita/ Umezeiro combination in comparison to the other

Table 2. Growth parameters of the peach cv. Chimarrita grafted on different rootstocks (Capdeboscq, Tsukuba1, and Umezeiro) throughout three years after grafting. Means from 4 repetitions. Values followed by different letters within a row are significantly different at $P<0.05$ according to Tukey's test.

\begin{tabular}{|c|c|c|c|c|c|}
\hline Growth parameters & & Year after grafting & Chimarrita/Capdeboscq & Chimarrita/Tsukubal & Chimarrita/Umezeiro \\
\hline $\begin{array}{l}\text { Pruning fresh mass }[\mathrm{g}] \\
\text { Leaf area }\left[\mathrm{cm}^{2}\right] \\
\text { Index of survival }[\%] \\
\text { Trunk diameter }[\mathrm{cm}]\end{array}$ & $\begin{array}{l}\text { scion } \\
\text { union } \\
\text { rootstock }\end{array}$ & $\begin{array}{l}1^{\text {st }} \text { and } 2^{\text {nd }} \\
2^{\text {st }} \\
3^{\text {rd }} \\
1^{\text {st }} \\
2^{\text {nd }} \\
3^{\text {rd }} \\
1^{\text {st }} \\
2^{\text {nd }} \\
3^{\text {rd }} \\
1^{\text {st }} \\
2^{\text {nd }} \\
3^{\text {rd }}\end{array}$ & $\begin{array}{r}4095.5^{\mathrm{a}} \\
14411.8^{\mathrm{a}} \\
100.0^{\mathrm{a}} \\
9.4^{\mathrm{a}} \\
22.9^{\mathrm{a}} \\
37.9^{\mathrm{a}} \\
15.9^{\mathrm{b}} \\
28.3^{\mathrm{b}} \\
44.1^{\mathrm{a}} \\
12.1^{\mathrm{a}} \\
24.8^{\mathrm{a}} \\
41.9^{\mathrm{a}}\end{array}$ & $\begin{array}{r}4519.5^{\mathrm{a}} \\
14578.6^{\mathrm{a}} \\
100.0^{\mathrm{a}} \\
11.7^{\mathrm{a}} \\
23.9^{\mathrm{a}} \\
39.3^{\mathrm{a}} \\
18.3^{\mathrm{a}} \\
32.3^{\mathrm{a}} \\
48.8^{\mathrm{a}} \\
14.7^{\mathrm{a}} \\
27.9^{\mathrm{a}} \\
42.5^{\mathrm{a}}\end{array}$ & $\begin{array}{r}1659.0^{\mathrm{b}} \\
7538.3^{\mathrm{b}} \\
90.0^{\mathrm{b}} \\
10.2^{\mathrm{a}} \\
19.8^{\mathrm{b}} \\
31.7^{\mathrm{b}} \\
19.0^{\mathrm{a}} \\
32.6^{\mathrm{a}} \\
49.9^{\mathrm{a}} \\
12.9^{\mathrm{a}} \\
22.1^{\mathrm{b}} \\
32.9^{\mathrm{b}}\end{array}$ \\
\hline
\end{tabular}




\section{A Chimarrita / Capdebosq Chimarrita / Tsukuba1 Chimarrita / Umezeiro}

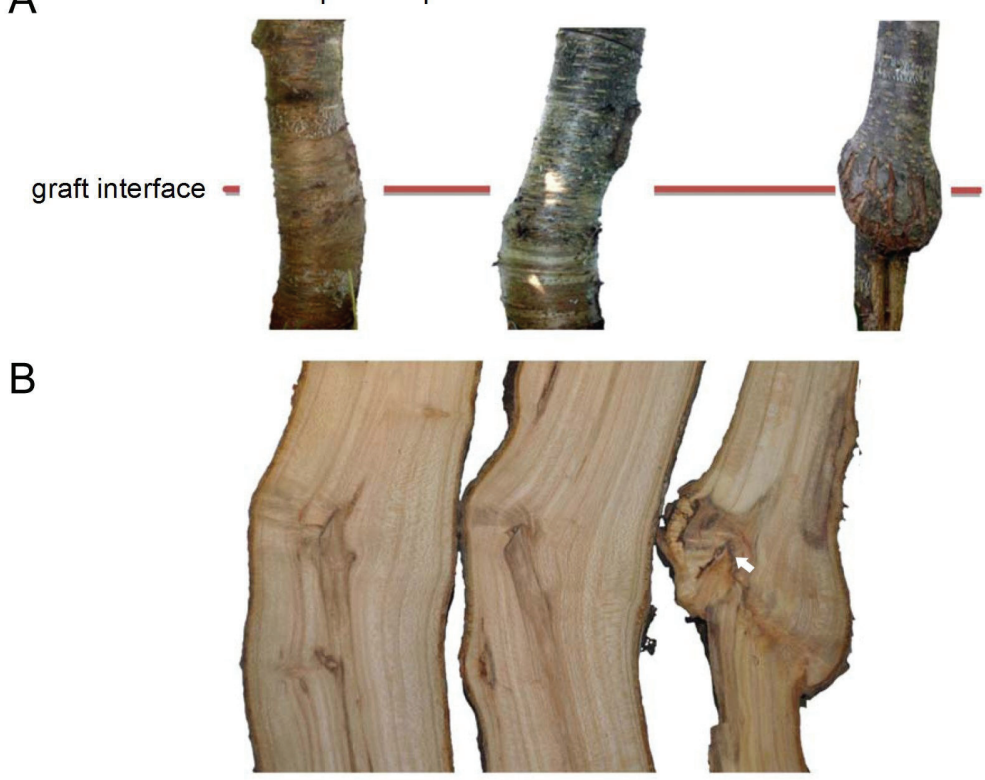

Fig. 1. $A$ - Overgrowth of the graft interface at the Chimarrita/Capdebosq, Chimarrita/Tsukuba 1, and Chimarrita/Umezeiro combinations. $B$ - Longitudinal sections through different graft unions (two years after grafting). White arrow shows a weak, poorly connected union with vascular discontinuity at the graft interface.

combinations tested (Table 2). Likewise, the Chimarrita/ Umezeiro combination showed a less trunk diameter of both the scion and rootstock together with overgrowth at the graft interface (Fig. $1 A$ ). On the other hand, SPAD values characterizing the chlorophyll content were not significantly different from those of trees grafted on Capdeboscq and Tsukuba1. The overgrowth at the graft interface, tree vigour reduction, and less index of survival in the Chimarrita/Umezeiro combination suggested symptoms of graft incompatibility (Herrero 1951, Mosse 1962, Moreno et al. 1993, Zarrouk et al. 2006). Despite that Umezeiro is considered as a promising rootstock for peach trees due to canopy vigour reduction, good fruit quality, and resistance to root-knot nematodes, these signs of incompatibility should be taken into account (Teles et al. 2009, Comiotto et al. 2012). Additionally, this peach/apricot combination also presented anatomical irregularities at the graft interface, characterized by vascular discontinuity (Herrero 1951). These results pointed out that the graft combination Chimarrita/ Umezeiro exhibited symptoms of both types of graft incompatibility (Fig. 1B). The coexistence of both types of incompatibility has been previously reported by other authors in some peach/plum combinations (Andrew and Marquez 1993, Zarrouk et al. 2006).

The involvement of certain enzymes in the graft union development has been studied in different Prunus species, especially enzymes involved in the phenylpropanoid pathway and lignification (Pina and Errea 2008, Zarrouk et al. 2010, Pina et al. 2012). In this study, we analyzed the transcription of $P A L$ genes in response to different scion-rootstock interactions. $P A L$ gene homologs were identified by querying the assembled and annotated peach genome on GDR with known PAL enzyme sequences from other plants. PAL seems to be encoded by at least two genes in the peach genome. There are two highly conserved $P A L$-like genes located on different chromosomes, PAL1 (chromosome 2) and PAL2 (chromosome 6), with $86 \%$ amino acid sequence identity. Based on these two genes, their expression patterns were investigated at the rootstock and scion partners of all combinations by real time qPCR. As there are no specific studies to identify suitable reference gene(s) for normalization of gene expression in graft (in-)compatibility experiments in Prunus, we tested four candidate reference genes to validate and develop a qRT-PCR method in graft combinations, including genes frequently used for internal control on expression studies: $A C T$ 11, TEF2, RP II, and peach EST, similar to the Arabidopsis thaliana gene (acc. No. At5g12240; Tong et al. 2009, Jimenez et al. 2010). In our study, the experimental conditions that could influence the housekeeping gene expression were different genotypes and different compatibility levels. The reference genes were screened for their specificity, presence of dimers in the dissociation curve, stability, and efficiency (Table 1). All the genes showed a good specificity by presence of a single band with the size expected and without dimer presence (data not shown). ACT 11 was the reference gene with the best stability calculated by the program NormFinder across the different samples and was selected for the normalization of the compatibility study in Prunus.

Gene expression analysis indicated that $P A L 1$ and $P A L 2$ were highly influenced by different combinations (Table 3). The Chimarrita/Umezeiro combination showed 


\section{DOS SANTOS PEREIRA et al.}

a higher expression of both $P A L$ genes than Chimarrita/ Capdeboscq and Chimarrita/Tsukubal in both graft partners. In the combination Chimarrita/Umezeiro, PAL1 in the scion was approximately eight- and five-fold more expressed than in Chimarrita/Capdeboscq and Chimarrita/ Tsukuba1, respectively. Likewise, $P A L 1$ in the rootstock was six- and three-fold more expressed in the Chimarrita/ Umezeiro combination than in Chimarrita/Capdeboscq and in Chimarrita/Tsukuba1. The same trend was obtained when the analysis was focused on PAL2 transcripts. According to $\mathrm{Ct}$ values, $P A L 1$ was more expressed than $P A L 2$, its mRNA content was 4 times higher when comparing samples from the different combinations. These results reveal an induction of both $P A L$ genes in incompatible combination at both graft partners two years after grafting but with higher $P A L 1$ than PAL2 expression. Although the PAL isoforms can play different functions, the peach $P A L$ genes are orthologous to other species where several authors suggest their involvement in cell wall lignification and flavonoid biosynthesis (Oh et al. 2003, Raes et al. 2003, Olsen et al. 2008). Differences in $P A L$ gene expression between compatible and incompatible combinations were found in apricot/plum combinations at early stages of graft development (Pina and Errea 2008). In this work, we observed that these differences were also displayed two years after grafting of the peach cultivar Chimarrita grafted onto the different rootstocks. Futhermore, two different PAL isoforms have been distinguished in this study. The PAL genes may be good markers for the study of compatibility due to the key role of PAL in the biosynthesis of many phenolic compounds. Grafting between species within a genus is successful in some cases but unsuccessful in others (Hartmann et al. 2002). This was the case in the incompatible graft combination Chimarrita/Umezeiro where both graft partners presented different genetic background (peach/apricot). Different studies have found phenolic compounds as potential causes for graft incompatibility (Errea 1998). Quantitative imbalance of phenolic compounds have been reported in incompatible combinations of apricot (Errea et al. 1992, Usenik et al. 2006, Pina and Errea 2008), plum (Rodrigues et al. 2001, Zarrouk et al. 2010), and cherry (Gebhardt and Feucht 1982, Treutter et al. 1986) grafted onto different rootstocks. The large number of Prunus combinations with quantitative alterations in the phenolic compound profiles indicates a consistent model for graft incompatibility.

To examine whether $P A L$ transcription was correlated with PAL activity, we measured the activity in both graft partners from the different combinations. PAL activity was clearly correlated with the total amount of $P A L$ transcripts in the rootstocks but not in the scions (Table 3). PAL activity was strongly increased at the

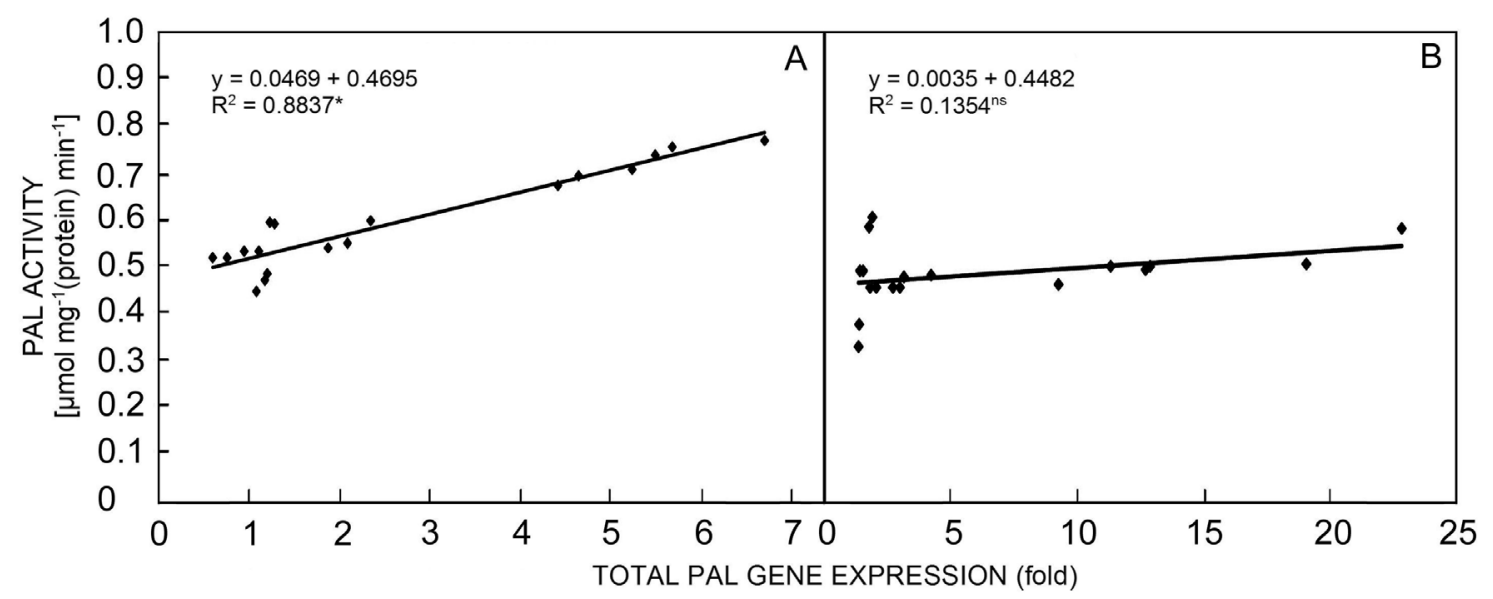

Fig. 2. Correlation between PAL activity and PAL transcription in the rootstock $(A)$ and the scion $(B)$ of Chimarrita/Capdeboscq, Chimarrita/Tsukuba1, and Chimarrita/Umezeiro combinations (two years after grafting). ${ }^{*}$ - correlation significant at $P<0.001$, ns - correlation not significant.

Table 3. Differential PAL1 and PAL2 gene expressions and PAL activities in scion and rootstock in different grafting combinations two years after grafting. Means $\pm \mathrm{SE}, n=6$. Values followed by different letters within the column are significantly different at $P<0.05$ (Tukey's multiple range test).

\begin{tabular}{|c|c|c|c|c|c|c|}
\hline Combination & \multicolumn{2}{|c|}{$\begin{array}{l}P A L 1 \text { expression } \\
\text { [fold] }\end{array}$} & \multicolumn{2}{|c|}{$\begin{array}{l}P A L 2 \text { expression } \\
\text { [fold] }\end{array}$} & \multicolumn{2}{|c|}{$\begin{array}{l}\text { PAL activity } \\
{\left[\mu \mathrm{mol}(\mathrm{t}-\mathrm{CA}) \mathrm{mg}^{-1} \text { (protein) } \mathrm{min}^{-1]}\right.}\end{array}$} \\
\hline Chimarrita/Capdeboscq & $1.27 \pm 0.08 \mathrm{~b}$ & $0.85 \pm 0.09 \mathrm{~b}$ & $0.26 \pm 0.04 \mathrm{~b}$ & $0.13 \pm 0.03 \mathrm{~b}$ & $0.47 \pm 0.04 \mathrm{a}$ & $0.55 \pm 0.01 \mathrm{~b}$ \\
\hline Chimarrita/Tsukuba1 & $2.14 \pm 0.20 \mathrm{~b}$ & $1.46 \pm 0.21 \mathrm{~b}$ & $0.65 \pm 0.23 b$ & $0.16 \pm 0.01 \mathrm{~b}$ & $0.45 \pm 0.01 \mathrm{a}$ & $0.52 \pm 0.02 b$ \\
\hline Chimarrita/Umezeiro & $10.73 \pm 1.73 \mathrm{a}$ & $4.91 \pm 0.32 \mathrm{a}$ & $3.95 \pm 0.49 \mathrm{a}$ & $0.44 \pm 0.03 \mathrm{a}$ & $0.50 \pm 0.02 \mathrm{a}$ & $0.72 \pm 0.02 \mathrm{a}$ \\
\hline
\end{tabular}


rootstock from the incompatible combination Chimarrita/ Umezeiro in comparison with the compatible ones two years after grafting. In this combination, PAL activity was 26 and $32 \%$ higher than those in Chimarrita/ Capdeboscq and Chimarrita/Tsukuba1, respectively. Likewise, Chimarrita/Umezeiro combination showed significant differences related to the activity of PAL between both graft partners (scion and rootstock) as seen at the transcriptional level. Hence, the changes of activity reflected changes of transcription, the PAL activity in the rootstock was $32 \%$ higher than in the scion. Interestingly, $P A L$ showed different transcript levels but not much different enzyme activity in the scions and rootstocks from the compatible combinations. In other studies, there are also cases where changes of transcription do not affect PAL enzyme activity due to posttranscriptional modification (Gibon et al. 2004, Osuna et al. 2007). The correlation between the $P A L$ transcription and the PAL activity in the different combinations is noted in Fig. 2. To generate this plot, the signals for the different transcripts (PAL1 and PAL2) were summed. Whereas the PAL activity was highly correlated with the total amount of the $P A L$ transcripts

\section{References}

Aloni, B., Cohen, R., Karni, L., Aktas, H., Edelstein, M.: Hormonal signaling in rootstock-scion interactions. - Sci. Hort. 127: 119-126, 2010.

Andersen, C.L., Jensen, J.L., Orntoft, T.F.: Normalization of real-time quantitative reverse transcription-PCR data: a model-based variance estimation approach to identify genes suited for normalization, applied to bladder and colon cancer data sets. - Adv. Cancer Res. 64: 5245-5250, 2004.

Andrew, P.K., Marquez, C.S.: Graft incompatibility. - Hort. Rev. 15: 183-231, 1993.

Anterola, A.M., Lewis, N.G.: Trends in lignin modification: a comprehensive analysis of the effects of genetic manipulations/mutations on lignification and vascular integrity. - Phytochemistry 61: 221-294, 2002.

Bradford, M.: A rapid and sensitive method for quantitation of microgram quantities of protein utilizing the principle of protein-dye binding, - Anal. Biochem. 72: 248-254, 1976.

Campos, A.D., Ferreira, A.G., Hampe, M.M.V., Antunes, I.F., Brancão, N., Silveira, E.P., Silva, J.B., Osório, V.A.: Induction of chalcone synthase and phenylalanine ammonia-lyase by salicylic acid and Colletotrichum lindemuthianum in common bean. - Braz. J. Plant Physiol. 15: 129-134, 2003.

Comiotto, A., Fachinelo, J.C., Hoffmann, A., Machado, N.P., Galarça, S.P., Betemps. D.L.: Vigour, flowering, yield and quality of 'Chimarita' and 'Maciel' for different rootstocks. - Cienc. Rural. 42: 788-794, 2012.

Dixon, R.A., Paiva, N.L.: Stress-induced phenylpropanoid metabolism. - Plant Cell 7: 1085-1097, 1995.

Ermel, F.F., Poessel, J.L., Faurobert, M., Catesson, A.M.: Early scion/stock junction in compatible and incompatible pear/pear and pear/quince grafts: a histo-cytological study. Ann. Bot. 79: 505-515, 1997.

Errea P.: Implications of phenolic compounds in graft incompatibility in fruit tree species. - Sci. Hort. 74: 195-
$\left(R^{2}=0.88\right)$ in the rootstocks from all combinations, there were no correlation between the PAL activity and the transcription in the scion $\left(R^{2}=0.13\right)$. In addition, it was expected that the scion partner from the incompatible combination would present more PAL activity, however, the high gene expressions of PAL1 and PAL2 in the scion Chimarrita grafted on the incompatible rootstock was not accompanied with high enzymatic activity.

In conclusion, this study shows the correlation between growth rate, $P A L$ gene expression, and PAL activity and graft compatibility. Different $P A L$ transcription in the different scion/rootstock combinations led to changes in the PAL activity in the rootstocks but not in the scions probably due to posttranslational regulation. These results contribute to better understanding the graft incompatibility phenomenon. Future studies detailing the specific role of each $P A L$ isoform on compatible and incompatible combinations as well as on silencing $P A L$ genes could advance in the scientific knowledge on this topic. It is expected that this research would become useful for association between physiological and molecular prediction of graft incompatibility in fruit trees.
205, 1998.

Errea, P., Felipe, A.: [Graft compatibility in apricot (Prunus armeniaca L.] - Invest Agr. Ser. Prod. Veg. 8: 67-77, 1993. [In Span.]

Errea.P,, Felipe, A., Herrero, M.: Graft establishment between compatible and incompatible Prunus spp. - J. exp. Bot. 45: 393-401, 1994.

Errea, P., Garay, L., Marin, J.A.: Early detection of graft incompatibility in apricot (Prunus armeniaca) using in vitro techniques. - Physiol. Plant. 112: 135-141, 2001.

Errea, P., Treutter, D., Feucht, W: Specificity of individual flavan3 -ols interfering with the grafting stress of apricots. - Angew. Bot. 66: 21-24, 1992.

Espen, L., Cocucci, M., Sacchi, G.A.: Differentiation and functional connection of vascular elements in compatible and incompatible pear/quince internode micrografts. - Tree Physiol. 25: 1419-1425, 2005.

Feucht, W., Treutter, D., Schmid, P.P.S.: Inhibition of growth and xylogenesis and promotion of vacuolation in Prunus callus by the flavanone prunin. - Plant. Cell. Rep. 7: 189192, 1988.

Gebhardt, K., Feucht, W.: Polyphenol changes at the union of Prunus avium $\times$ Prunus cerasus grafts. - J. hort. Sci. 57: 253-258, 1982.

Gibon, Y., Blaesing, O.E., Hannemann, J., Carillo, P., Höhne, M., Hendriks, J.H.M., Palacios, N., Cross, J. Selbig, J., Stitt, M.: A robot-based platform to measure multiple enzyme activities in Arabidopsis using a set of cycling assays: comparison of changes of enzyme activities and transcript levels during diurnal cycles and in prolonged darkness. Plant Cell 16: 3304-3325, 2004.

Hartmann, H.T., Kester, D.E., Davies, F.T., Geneve, R.L. (ed): Plant Propagation: Principles and Practices. - Prentice-Hall, New Jersey 2002.

Herrero, J.: Studies of compatible and incompatible graft 
combinations with special reference to hardy fruit trees. - J. hort. Sci. 26: 186-237, 1951.

Jiménez, S., Li, Z., Reighard, G.L., Bielenberg, D.G.: Identification of genes associated with growth cessation and bud dormancy entrance using a dormancy-incapable tree mutant. - BMC Plant Biol. 10: 10-25, 2010.

Jin, X.Q., Chen, Z.W., Tan, R.H., Zhao, S.J., Hu, Z.B.: Isolation and functional analysis of 4-coumarate:coenzyme A ligase gene promoters from Salvia miltiorrhiza. - Biol Plant. 56: 261-268, 2012.

Kubota, N.H., Yakushiji, H., Nishiyama, N., Mimura, H., Shimamura, K.: Phenolic contents and L-phenylalanine ammonia-lyase activity in peach fruit as affected by rootstocks. - J. jap. Soc. hort. Sci. 70: 151-156, 2001.

Leng, P., Qui, J.X.: Effect of anthocyanin on David peach (Prunus davidiana Franch) under low temperature stress. Sci. Hort. 97: 27-39, 2003.

Messias, R.S., Galli, V., Silva, S.D.A., Schirmer, M.A., Pillon, C. N.: Extraction RNA methodologies and semi quantitative gene expression evaluation of maize secondary metabolism. - Bol. Pesq. Desenvolv. 117: 1-26, 2010.

Mng'omba, S.A., Du Toit, E.S., Akinnifesi, F.K.: The relationship between graft incompatibility and phenols in Uapaca kirkiana Muell Arg. - Sci. Hort. 117: 212-218, 2008.

Moore, R., Walker, D.B.: Studies on vegetative compatibilityincompatibility in higher plants. I. A structural study of a compatible autograph in Sedum telephoides (Crassulaceae). - Amer. J. Bot. 68: 820-830, 1981.

Moreno, M.A., Moing, A., Lansac, M., Gaudillere, J.P., Salesses, G.: Peach Myrobalan plum graft incompatibility in the nursery. - J. hort. Sci. 68: 705-714, 1993.

Mosse, B.: Graft incompatibility in fruit trees. - Tech. Commun. Commonwealth Bureau hort. Plant Crops 28: 1-36, 1962.

Oh, S., Park, S., Han, K.-H.: Transcriptional regulation of secondary growth in Arabidpsis thaliana. - J. exp. Bot. 54: 2709-2722, 2003.

Olsen, K.M., Lea, U.S., Slimestad, R., Verheul, M., Lillo, C.: Differential expression of four Arabidopsis $P A L$ genes; $P A L 1$ and $P A L 2$ have functional specialization in abiotic environmental-triggered flavonoid synthesis. - J. Plant Physiol. 165: 1491-1499, 2008.

Osuna, D., Usadel, B., Morcuende, R., Gibon, Y., Bläsing, O.E., Höhne, M., Günter, M., Kamlage, B., Trethewey, R., Scheible, W.R., Stitt, M.: Temporal responses of transcripts, enzyme activities and metabolites after adding sucrose to carbon-deprived Arabidopsis seedlings. - Plant J. 49: 463491, 2007.

Pina, A., Errea, P.: A review of new advances in mechanism of graft compatibility-incompatibility. - Sci. Hort. 106: 1-11,
2005.

Pina, A., Errea, P.: Differential induction of phenylalanine ammonia-lyase gene expression in response to in vitro callus unions of Prunus spp. - J. Plant Physiol. 165: 705714, 2008.

Pina, A., Zhebentyayeva, T., Errea, P., Abbott, A.: Isolation and molecular characterization of cinnamate 4-hydroxylase from apricot and plum. - Biol. Plant. 56: 441-450, 2012.

Raes, J., Rohde, A., Christensen, J.H., Van de Peer, Y., Boerjan, W.: Genome-wide characterization of the lignification toolbox in Arabidopsis. - Plant Physiol. 133: 1051-1071, 2003.

Reighard, G.L.: Peach rootstocks for the United States: are foreing rootstocks the answer? - Horttechnology 10: 714718, 2000.

Rodrigues, A.C., Machado, L.B., Diniz, A.C., Fachinello, J.C., Fortes, G.R.L.: [Evaluation of the graft compatibility in Prunus sp.] - Rev. Bras Frut. 23: 359-364, 2001.[In Port.]

Ruijter, J.M., Ramakers, C., Hoogaars, W.M., Karlen Y, Bakker, O., Van Den Hoff, M.J., Moorman A.F.: Amplification efficiency: linking baseline and bias in the analysis of quantitative PCR data. - Nucl. Acids Res. 37 (Suppl.): e45, 2009.

Sullivan, M.L.: Phenylalanine ammonia lyase genes in red clover: expression in whole plants and in response to yeast fungal elicitor. - Biol. Plant. 53: 301 - 306, 2009.

Teles, C.A., Biasi, L.A., Mindêllo Neto, U.R. Deschamps, C.: [Total phenols content, peroxidase activity and their relationship with the compatibility of the intergrafted seedlings of peach tree.] - Cienc. Agrotec. 33: 86-91, 2009. [In Port.]

Tong, Z., Gao, Z., Wang, F., Zhou, J. Zhang, Z.: Selection of reliable reference genes for gene expression studies in peach using real-time PCR. - BMC Mol Biol. 10: 1-13, 2009.

Treutter, D., Feucht, W., Schmid, P.P.S.: [Polyphenols of the phloem in relation to incompatibility of interspecific Prunus graftings (Prunus avium L,, Prunus cerasus L.). I. Flavanones and flavanols above the graft union.] Gartenbauwissenschaft 51: 77-84, 1986. [In German]

Usenik, V., Krska, B., Vican, M., Stampar, F.: Early detection of graft incompatibility in apricot (Prunus armeniaca L.) using phenol analyses. - Sci. Hort. 109: 332-338, 2006.

Zarrouk, O., Gogorcena, Y., Moreno, M.A., Pinochet, J.: Graft compatibility between peach cultivars and Prunus rootstocks. - Hortscience. 41: 1389-1394, 2006.

Zarrouk, O., Testillano, P.S., Risueno, M.C., Moreno, M.A., Gogorcena, Y.: Changes in cell/tissue organization and peroxidase activity as markers for early detection of graft incompatibility in peach/plum combinations. - J. amer. Soc. hort. Sci. 135: 9-17, 2010. 
